\title{
A REFORMA TRIBUTÁRIA, AS EXPORTAÇÕES E OS ESTADOS
}

Aloísio Tupinambá Gomes Neto ${ }^{1}$

Marcos Mendes ${ }^{2}$

A principal conclusão de recente reunião entre o Presidente e os governadores, sobre a reforma tributária, foi o compromisso da União de pagar uma compensação aos estados pela não incidência do ICMS sobre as exportações. O pleito imediato dos governadores é por dinheiro, e ponto final. E o que os interessa, no momento, é achar fontes de recursos: CIDE, CPMF, Imposto sobre Importação ou outra opção que surgir.

A compensação financeira às exportações é justa e deve ser paga. Porém, o mais interessante é que a sua criação gera uma ótima oportunidade para se construir um eficiente mecanismo de estímulo às exportações. Coerente, portanto, com o objetivo final da reforma tributária, que é, justamente, aumentar a eficiência e a competitividade externa da economia nacional.

Atualmente, não há qualquer motivo para que um governo estadual trabalhe a favor das exportações. Pelo contrário, devido à isenção de ICMS às exportações, se a sua economia se internacionalizar a sua arrecadação de ICMS murchará. Isso precisa mudar, porque a ação estadual é peça fundamental para que as exportações deslanchem.

São os governos estaduais que fornecem boa parte da infraestrutura e logística públicas de que necessitam as empresas. Garantem adequado acesso aos portos de embarque. Podem facilitar a oferta de armazéns, de portos secos e de outros instrumentos importantes para o desembaraço aduaneiro de mercadorias. Fornecem, ainda, serviços públicos utilizados pelos exportadores, a exemplo de

${ }^{1}$ Professor de Economia Internacional do UniCeub. Mestre em Economia pela Universidade de Urbana - Champaign - Illinois - EUA.

${ }^{2}$ Consultor Legislativo do Senado. Doutor em Economia pela USP.

Universitas - Relações Int., Brasília, v. 2, n.1, p. 9-11, jan./jun. 2004 
cursos de capacitação da mão-de-obra. Conhecem as potencialidades produtivas locais e, por isso, são capazes de articular o desenvolvimento de cadeias produtivas de exportação no âmbito de suas políticas de industrialização e emprego. Podem, também, coordenar esforços junto aos municípios para desonerar os exportadores de tributos municipais.

Para estimular os estados a tomar atitudes favoráveis à exportação, nada mais lógico do que a União lhes pagar um prêmio pelo bom desempenho exportador. Para que esse incentivo funcione, é fundamental que o pagamento a cada estado seja proporcional aos respectivos volumes de exportação.

Atualmente, os estados já recebem uma compensação pela desoneração tributária de produtos primários, instituída pela Lei Kandir. Mas esta Lei estabeleceu um valor fixo por estado, que não é afetado pela performance exportadora de cada um deles. A cada ano o Governo Federal define, no orçamento, o montante da compensação, e esta é dividida de acordo com os percentuais fixados na Lei. Não há estímulo a cada estado para aumentar suas exportações e, com isso, ampliar a fatia a que faz jus na verba compensatória.

Por isso, a nova regra de partilha deveria ter critério "móvel". Por exemplo, a participação de cada estado nas exportações totais nos doze meses anteriores àquele em que se está pagando a compensação. Aquele que conseguir, mês a mês, aumentar sua participação no total das exportações vai, paulatinamente, receber mais recursos.

Não se pode, contudo, usar apenas este critério, sob pena de não estimular atitudes pró-exportação dos estados que têm pequena participação nas exportações totais. Por isso, seria interessante que parte da compensação (digamos 10\%) fosse dividida de acordo com o crescimento percentual das exportações de cada estado.

Tomemos um exemplo simples, supondo que existam apenas três estados hipotéticos. Os valores exportados por cada um deles, em dois períodos consecutivos de 12 meses, são mostrados na tabela a seguir.

Universitas - Relações Int., Brasília, v. 2, n.1, p. 9-11, jan./jun. 2004 


\begin{tabular}{crrr}
\hline Estado & jul 2001- jun 2002 & jul 2002 - jun 2003 & $\begin{array}{c}\text { Crescimento da Exportação } \\
\text { de cada Estado }\end{array}$ \\
\hline A & $\$ 48$ & $\$ 50$ & $4,2 \%$ \\
B & $\$ 35$ & $\$ 40$ & $14,3 \%$ \\
C & $\$ 5$ & $\$ 10$ & $100,0 \%$ \\
TOTAL & $\$ 88$ & $\$ 100$ & $13,6 \%$ \\
\hline
\end{tabular}

No mês de julho de 2003, tomando os últimos doze meses, o estado A vai ser o principal beneficiado pelo primeiro critério (divisão de acordo com a participação do estado no total das exportações) pois, sozinho, é responsável por metade das exportações do país (\$ 50 em \$ 100). Já o estado $C$, que leva a menor parcela pelo primeiro critério, por ser responsável por apenas $10 \%$ das exportações nacionais, será o principal beneficiário do segundo critério (crescimento das próprias exportações), pois obteve uma expansão de suas exportações da ordem de $100 \%$ na comparação dos dois períodos.

A combinação dos dois critérios geraria uma saudável competição entre os estados. Não bastaria ter um grande volume de exportações, seria preciso ampliá-las a um ritmo superior ao dos outros estados. O resultado seria a substituição da atual guerra fiscal predatória por uma saudável competição por mercados externos.

Por outro lado, é preciso evitar usar como critério a redução das importações ou a ampliação do saldo comercial do estado, pois isso estimularia as unidades federadas a criar barreiras administrativas às importações, gerando ineficiência no processo produtivo.

Não se trata, portanto, de "arranjar algum dinheiro" para os estados no processo de barganha para aprovação da reforma tributária. Mas sim de criar um mecanismo visando agregar ao esforço exportador da União a participação de parceiros estratégicos que são os estados. Isto sim seria coerente com os objetivos finais da reforma tributária.

\section{Referência bibliográfica}

Kreps, David M. A course in microeconomic theory. Prentice Hall, Essex, Inglaterra. 1990. Capítulo 5.

Universitas - Relações Int., Brasília, v. 2, n.1, p. 9-11, jan./jun. 2004 